\title{
A humanitarian response to the West African Ebola virus disease outbreak
}

\author{
Linda M. Mobula ${ }^{1 *} \mathbb{D}$, Jolene H. Nakao ${ }^{1,2}$, Sonia Walia ${ }^{1}$, Justin Pendarvis ${ }^{1}$, Peter Morris ${ }^{1}$ and David Townes ${ }^{1,2}$
}

\begin{abstract}
The 2014-2016 Ebola virus disease (EVD) outbreak in West Africa was of unprecedented magnitude with a total of 28,616 suspected, probable, and confirmed cases reported in Guinea, Liberia, and Sierra Leone.

The international humanitarian community utilized its expertise in rapid response and scale up in emergency situations to manage a threat different from the more common humanitarian emergencies resulting from conflict or natural disaster. Unique multisectoral partnerships forged between traditional public health actors and humanitarian actors facilitated mutual learning and opened the door to ongoing working relationships that will hasten efficient and effective response to future global public health emergencies.
\end{abstract}

Keywords: Ebola virus disease, Humanitarian, West Africa

\section{Introduction}

The 2014-2016 Ebola virus disease (EVD) outbreak in West Africa was of unprecedented magnitude with a total of 28,616 suspected, probable, and confirmed cases reported in Guinea, Liberia, and Sierra Leone as of June 2016 (WHO Ebola Virus Disease Situation Report 2016). Historically, EVD outbreaks were smaller in scale with limited geographic spread, typically occurring in remote villages in rural areas in Central and West Africa, including in the Democratic Republic of the Congo, Uganda, Ivory Coast, and Gabon. For the first time in history, an EVD outbreak affected multiple countries at once, including densely populated urban centers. On August 8, 2014, the World Health Organization (WHO) declared the EVD outbreak to be a Public Health Emergency of International Concern (PHEIC), due to the risk of international spread of disease and the need for a coordinated international response (WHO Ebola Virus Disease Situation Report 2016). We briefly describe the unique features of this outbreak that necessitated an international humanitarian response, including multisectoral partnerships between traditional public health actors and non-traditional public health actors, and implications for the future.

\footnotetext{
*Correspondence: mmobula@usaid.gov

${ }^{1}$ Office of US Foreign Disaster Assistance, United States Agency for International Development, 1300 Pennsylvania Ave, NW, Washington, DC 20523, USA Full list of author information is available at the end of the article
}

\section{Past EVD outbreaks}

EVD, previously known as Ebola hemorrhagic fever, was first documented in 1976 in two outbreaks: one in Yambuku Village, in the Democratic Republic of the Congo (DRC; then Zaire), and a near-simultaneous outbreak in the town of Nzara in South Sudan (Peters and LeDuc 1999; Breman et al. 2016; Heymann et al. 1999; Rosello et al. 2015; Kerstiëns and Matthys 1999). In August 1976, the Yambuku Village index case-patient presented with a hemorrhagic fever syndrome to the Yambuku Mission Hospital in DRC. The causative agent was isolated from a blood sample obtained from a second patient, a Belgian nun, and named Ebola virus, after the Ebola River in DRC (Heymann et al. 1999). The strategy developed to control the Zaire outbreak, refined by experience, comprised the basic tenets by which future outbreaks were controlled: early identification, isolation, and case management; effective infection control; rigorous contact tracing; reliable laboratory testing; rapid, safe, and culturally sensitive burials; and appropriate community engagement (Peters and LeDuc 1999).

Since those initial outbreaks, 21 subsequent EVD outbreaks were recorded worldwide until 2014, including six in the DRC and five in Uganda (Peters and LeDuc 1999; Heymann et al. 1999). The 1995 outbreak in Kikwit, DRC, is the most studied Ebola outbreak, providing much of the data on the epidemiology of EVD (Rosello et al. 2015). Until the West African outbreak in 
2014, the largest recorded Ebola outbreak occurred in 2000 in the northern Ugandan district of Gulu, which borders Sudan; a total of 425 cases and 224 deaths were reported (Bazeyo et al. 2015).

\section{West African Ebola outbreak (2014-2016)}

In March 2014, hospitals in the Forest Region of Guinea reported clusters of an unidentified illness characterized by fever, severe diarrhea, and vomiting (Baize et al. 2014). On March 21, 2014, Ebola was laboratory confirmed, and the Government of Guinea declared its first Ebola outbreak, approximately 3 months after the suspected index case-patient developed symptoms in December 2013 (Baize et al. 2014; Médicins sans Frontières, Stockholm Evaluation Unit 2016). Médecins Sans Frontières (MSF) deployed multi-disciplinary teams to set up an Ebola treatment unit (ETU) in Guekedou, Guinea, and initiated outbreak control measures (Médicins sans Frontières, Stockholm Evaluation Unit 2016). WHO's Global Alert and Response Network (GOARN) and the US Centers for Disease Control and Prevention (CDC) deployed staff to support national efforts to stop transmission. WHO also sent a team to Guinea at that time to provide support for infection prevention and control (IPC) (Key Events in the WHO Response to Ebola 2015).

At the end of March, MSF notified the international community that this outbreak was not typical of previous outbreaks and additional international support was critical, thus requesting further assistance from the humanitarian community. Though the outbreak appeared to wane in April 2014, cases were detected in Sierra Leone in May. By late July, the outbreak had spread to major urban centers in Guinea, Liberia, and Sierra Leone (Médicins sans Frontières, Stockholm Evaluation Unit 2016).

The caseload continued to climb due to multiple factors, some of which distinguished this outbreak from those prior. The disease reached densely populated urban centers where transmission occurred rapidly; movement of ill persons and contacts across national borders led to wide geographic spread (Alexander et al. 2015; Bell et al. 2016; Dahl et al. 2016a; World Health Organization 2015). In addition, lack of experience treating EVD and responding to an Ebola outbreak, poor infection control in health facilities, unsafe burial practices, limited isolation and treatment capacity, the presence of unknown chains of transmission, and lack of strong disease surveillance systems furthered the spread (Alexander et al. 2015). Community resistance to public health measures, including isolation and contact tracing, as well as mistrust of the government and ETUs, attempts to hide the deceased, continuation of traditional burial practices, and subsequent reluctance to seek care complicated the response.

\section{The humanitarian response}

The outbreak continued to intensify, and the crisis evolved into a complex humanitarian emergency, marked by the complete breakdown of services and significant loss of human life. The response required coordinated international support beyond the capabilities of any single agency or ongoing United Nations (UN) country program and actors to address both disease transmission and the humanitarian impacts across the region (USAID 2016; Dahl et al. 2016b). Isolation and treatment capacity was overwhelmed and routine health services ceased to function, as health care workers contracted Ebola and human and financial resources were redirected to support the response. Businesses and schools closed; airlines ceased flights into Ebola-affected countries, resulting in loss in gross domestic product of $\$ 2.2$ billion according to the World Bank (World Bank Group 2015). Isolation of suspected case-patients impacted agricultural production; restrictions on the movement of people and goods resulted in limited labor supply, which led to worsening food insecurity (United National Development Group 2015). Significant humanitarian protection needs were identified, including a rise in the number of vulnerable children who had lost one or both parents, and stigmatization of survivors with increased reports of violence both towards survivors and humanitarian responders. Voluntary repatriation of thousands of Ivorian refugees who had fled to Liberia during civil unrest in 2010 was suspended due to the closed borders and fears of spreading Ebola (Protection and Security, Ebola in West Africa, ACAPS Briefing Note 2014).

On June 27, 2014, the Ebola outbreak was declared a Grade 3 emergency by WHO, given the scale and complexity of the emergency, urgency of need for life-saving assistance, and limited capacity of host governments to respond (Key Events in the WHO Response to Ebola 2015). Despite growing awareness of the problem, too few health actors with viral hemorrhagic fever expertise, along with disjointed coordination mechanisms, challenged an effective scale up of response.

Both traditional public health actors and humanitarian actors were obliged to adapt their regular roles in order to provide urgent assistance at the scale that was required to interrupt transmission of EVD. We refer to traditional public health actors as those who commonly work in public health or respond to public health emergencies, including national health providers and authorities, WHO, CDC, and non-governmental organizations (NGOs). We refer to humanitarian actors, on the other hand, as the entities who typically respond to humanitarian emergencies, including UN agencies and international organizations, also including some NGOs. There is some overlap between these two designations, 
as many humanitarian actors also have experience in public health, including response to disease outbreaks in the context of conflict, natural disaster, and complex emergencies. Additionally, several "traditional public health actors" with expertise in responding to VHF outbreaks also have experience in humanitarian emergencies, including MSF and WHO. Traditional development actors, including those working in public health, who had a long standing presence in country, also played a significant role. They had to work within the humanitarian architecture, yet unfamiliar to them, potentially made more difficult in the absence of the cluster approach and a Health Cluster, the typical mechanism which facilitates coordination among health actors during an emergency (Reference Module for Country Coordination at Country Level, Interagency Standing Committee 2015). Together, they provided support to host governments in implementing strategies and building critical response infrastructure. With few actors having expertise in EVD, humanitarian and global health partners worked together to constantly re-evaluate and adjust strategies to address the complex and dynamic nature of the epidemic. An unprecedented number of agencies combined their efforts with those of the national governments to help contain the outbreak and mitigate second-order impacts.

As the lead coordinator for USG international disaster response, USAID's Office of US Foreign Disaster Assistance (USAID/OFDA) served as the "backbone" of the US' EVD response, coordinating efforts among other USG entities that provided needed expertise, including CDC, the US military, and the US Public Health Service. USAID/OFDA contributed to the response through financial and operational support to over 30 regional and local implementing partners, technical support to national response systems, and coordination of these programs with other USG resources committed to the response. Through USAID, the USG deployed a field-based Disaster Assistance Response Team (DART) on August 5 and established a corresponding Response Management Team (RMT) based in Washington, D.C. The DART-comprising disaster response, public health and medical experts from USAID/OFDA and CDC-worked on coordinating the interagency response, and identifying key needs stemming from the EVD outbreak, in order to amplify humanitarian response efforts, and lead USG efforts to support the EVD response. While USAID/OFDA coordinated the USG's overall response, CDC provided vital technical leadership and guidance in the areas of surveillance, epidemiology, and infection prevention and control.

From August 2014 to December 2016, USAID/OFDA provided more than $\$ 809$ million across the three countries to UN agencies, NGO implementers, and contractors supporting critical interventions such as health and humanitarian coordination, case management, surveillance and epidemiology, restoration of essential health services through infection prevention and control measures, water and sanitation hygiene (WASH) interventions, social mobilization and communications, and logistics activities, including the procurement of personal protective equipment and relief commodities (Dahl et al. 2016b). In addition, USAID/OFDA provided support to critical training activities for health care workers focused on case management, infection prevention and control, and contact tracing (Fig. 1).

A paradigm shift with new partnerships between humanitarian actors, traditional public health agencies, donors, and multilateral organizations was essential. As an example, in Liberia, this collaboration took the form of a consortium of five organizations, including development actors already on the ground working in public health, supporting county health teams and individual health facilities, with significant in-country experience and expertise. Some of these organizations engaged their emergency divisions, and all of them adapted to evolving needs. In the absence of a Health Cluster, amidst a nascent national-level government-led Incident Management System, the consortium helped to streamline coordination, particularly in Montserrado County, by focusing on gaps including the link between case management and contact tracing. One organization with expertise in water and sanitation expanded their purview to address the need for safe and dignified burials (Fig. 2). Public health actors, with existing relationships and familiarity with local communities and their practices, had established trust which facilitated successful programs, especially those with community engagement and education at their core. Humanitarian actors' readiness for action and ability to rapidly scale enhanced these programs.

The Guinean National Ebola Coordination Cell launched "micro-cerclage," a strategy consisting of

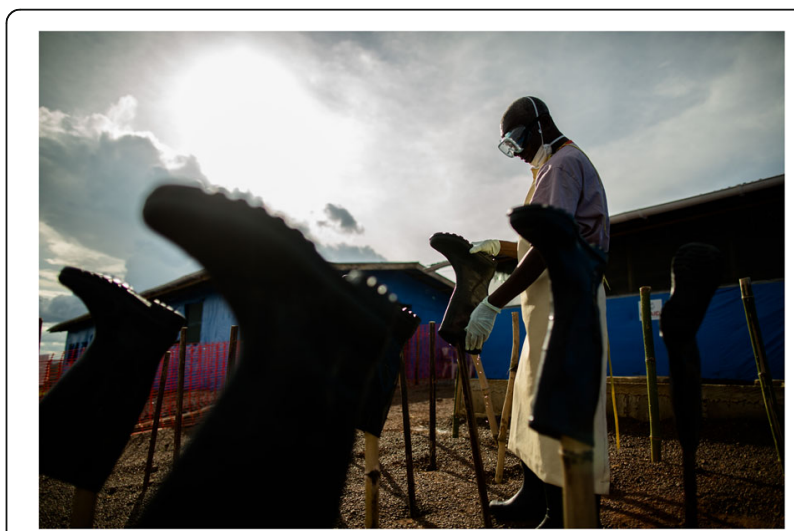

Fig. 1 Suakoko, Bong County, Liberia, October 7, 2014: health care worker disinfecting boots at the Bong County Ebola treatment unit. Photo by Morgana Wingard, USAID 


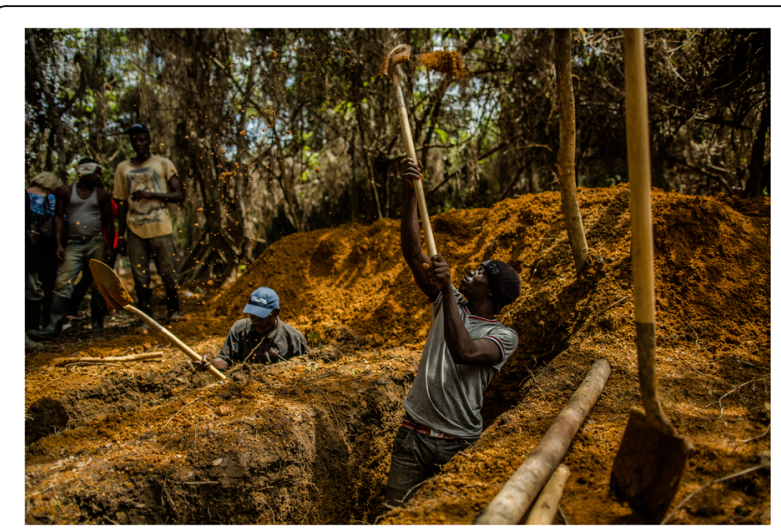

Fig. 2 Suakoko, Bong County, Liberia: workers conducting safe and dignified burials at the Bong County Ebola treatment unit. Photo by Morgana Wingard, USAID

limited movement in and out of affected villages in order to encourage communities to remain within a circumscribed area (home or village) (Dahl et al. 2016b). This was accompanied by the distribution of bags of rice and oil to families, door-to-door case finding, and monitoring of illnesses and deaths within the last 21 days. This strategy was launched in an effort to mitigate community resistance to recommended public health measures and was a prime example of how humanitarian actors partnered with traditional public health actors to contain the outbreak. Traditional public health actors conducted routine surveillance activities, such as contact tracing and active case finding, while humanitarian actors distributed cash and food.

Humanitarian actors supported the scale up of national disease surveillance; established isolation and treatment capacity; provided safe, dignified, and culturally appropriate burials; implemented infection prevention and control measures; enhanced nationwide community mobilization; and bolstered logistics, including supply chain for health facilities. In-kind food and cash assistance to communities in voluntary isolation became critical to prevent disease transmission through movement of contacts and worsening food insecurity. In order to facilitate effective coordination of the response across multiple countries with limited air transport, the UN Humanitarian Air Service quickly transported personnel and critical supplies. The World Food Program (WFP) reapplied their expertise with food delivery to vulnerable populations to target isolated individuals.

In Ebola-affected countries, several development partners successfully pivoted from their health systems strengthening activities to provide IPC training at health facilities. One example of this is a USAID-funded development partner who provided technical assistance for IPC in Guinea, as part of their Maternal Child Survival Program. This partner began to rapidly deploy staff to provide critical training for health care personnel at routine non-Ebola health facilities in areas with active EVD transmission, given that poor infection control results in increased transmission among health care workers (Grinnell et al. 2015). Traditional public health and humanitarian partners together adopted a ring IPC strategy, which was introduced in areas of active Ebola transmission to help break the chain of transmission. Ring IPC aimed to provide intensive, short-term supervision for compliance with normative IPC guidelines in a designated area surrounding recent cases or case clusters and to ensure that facilities had adequate stocks of essential IPC supplies (Nyenswah et al. 2015; Olu et al. 2015). This strategy allowed partners to rapidly provide interventions in areas where there had not been formal training in IPC, in order to mitigate active transmission.

Social mobilization had not typically been part of the traditional humanitarian coordination system (Dubois and Wake 2015). This changed during the Ebola response, as the need to couple standard public health interventions with community engagement and social mobilization efforts became critical, due to mistrust and increased community resistance towards the response. In September 2014, at least eight officials and local journalists were brutally murdered in the village of Womey, Guinea. They had been sent as part of a delegation to conduct education on Ebola (Callimachi 2014). Several rumors about being poisoned at ETUs and false messages about Ebola being a manufactured weapon circulated throughout the outbreak in Liberia, Guinea, and Sierra Leone. During a community meeting in a sub-prefecture in Western Guinea, a survivor described receiving phone calls from his community while he was admitted to an ETU. Due to the fear of being poisoned, he was told to "spit out" prescribed pills and to disconnect intravenous lines when nobody was watching. He instead decided to comply with his medical care and survived, while many of his friends died. After his discharge, he was able to explain to his community that adhering to treatment increases chances of survival. Other community members confirmed they had also received messages emphasizing the need to reject all form of treatment. Therefore, the inclusion of social mobilization as a response pillar became necessary (Gillespie et al. 2016).

An additional unique feature of the Ebola response in West Africa was the integration of the WHO ring vaccination trial conducted in Guinea as part of an ongoing response effort-the first time an Ebola vaccine was used in a clinical trial as part of an ongoing response effort. Preliminary results from a ring vaccination trial conducted in Guinea had indicated that administration of a single dose of rVSV-ZEBOV to primary and secondary contacts of confirmed EVD case-patients was effective in preventing EVD infection (Henao-Restrepo et al. 2015). 
The Government of Guinea adopted ring vaccination as an integral part of response activities, when a cluster of Ebola cases emerged in the Forest region of Guinea in 2016, from sexual transmission from a survivor (Ebola ça Suffit Ring Vaccination Trial Consortium 2015; Gsell et al. 2017).The incorporation of a vaccination trial, often on a development timeline, into the ongoing response was coordinated with the National Ebola Coordination cell with other humanitarian interventions.

The rVSV ring vaccination campaign was launched on May 21, 2018, as part of the response effort to the Ebola virus disease outbreak in the Democratic Republic of the Congo (World Health Organization, Ebola Virus Disease External Situation Report 2018).

With its experience in rapid response and scale up in emergency situations, the international humanitarian community galvanized to manage a threat different from the more common humanitarian emergency, resulting from conflict or natural disasters. Leveraging previous experience with humanitarian emergencies and flexible response mechanisms allowed rapid scale up and facilitated the development of new operational models for evolving technical guidance, including guidance on the prevention of sexual transmission, use of vaccines, and breastfeeding in survivors.

\section{Conclusion}

Given its scale and scope, the 2014-2016 Ebola outbreak in West Africa required an unprecedented collective response requiring strong and unprecedented coordination between a variety of actors, including traditional public health actors and development and humanitarian actors. While traditional public health actors with previous experience in Ebola response provided their expertise, development actors provided in country experience due to their longstanding presence, along with knowledge and the trust of the local communities, and the international humanitarian community provided experience working within the humanitarian architecture and the ability to rapidly scale up a response. This combination played a pivotal role in mounting the immense response needed to control the largest Ebola outbreak in history. Operational coordination, the scale and speed of logistics needed, and the need for immediate action were key challenges that the humanitarian framework helped address. The unique multisectoral partnerships forged between traditional public health and humanitarian actors facilitated mutual learning and opened the door to ongoing working relationships that will improve response to future global public health emergencies.

\section{Abbreviations}

CDC: US Centers for Disease Control and Prevention; DART: Disaster Assistance Response Team; DRC: Democratic Republic of the Congo; ETU: Ebola treatment unit; EVD: Ebola virus disease; GOARN: Global Alert and Response Network;
MSF: Médecins Sans Frontières; NGO: Non-governmental organization; OFDA: Office of US Foreign Disaster Assistance; PHEIC: Public Health Emergency of International Concern; RMT: Response Management Team; UN: United Nations; USAID: United States Agency for International Development; USG: United States Government; WFP: World Food Program; WHO: World Health Organization

\section{Acknowledgements}

The authors would like to thank all the unsung heroes of the Ebola response for their sacrifice and commitment to bring an end to a horrific outbreak that took away thousands of lives.

Availability of data and materials

Data for this study can be found in the USAID Development Experience Clearing house (https://dec.usaid.gov/dec/home/Default.aspx).

\section{Authors' contributions}

The views and opinions represented in this article do not represent the views and opinions of the US Agency for International Development. All authors read and approved the final manuscript.

\section{Competing interests}

The authors declare that they have no competing interests.

\section{Publisher's Note}

Springer Nature remains neutral with regard to jurisdictional claims in published maps and institutional affiliations.

\section{Author details}

'Office of US Foreign Disaster Assistance, United States Agency for International Development, 1300 Pennsylvania Ave, NW, Washington, DC 20523, USA.

${ }^{2}$ Emergency Response and Recovery Branch, Division of Global Health Protection, Center for Global Health, Centers for Disease Control and

Prevention, 1600 Clifton Road, Atlanta 30329, GA, USA.

Received: 27 December 2017 Accepted: 13 June 2018

Published online: 01 August 2018

\section{References}

Alexander KA, Sanderson CE, Marathe M, Lewis BL, Rivers CM, Shaman J et al (2015) What factors might have led to the emergence of Ebola in West Africa? PLoS Negl Trop Dis 9(6):e0003652.

Baize S, Pannetier D, Oestereich L, Rieger T, Koivogui L et al (2014) Emergence of Zaire Ebola virus disease in Guinea_preliminary report. N Engl J Med 371: 1418-1425.

Bazeyo W, Bagonza J, Halage A, Okure G, Mugagga M, Musoke R, Tumwebaze M, Tusiime S, Ssendagire S, Nabukenya I, Pande S, Aanyu C, Etajak S, Rutebemberwa E (2015) Ebola a reality of modern public health; need for surveillance, preparedness and response training for health workers and other multidisciplinary teams: a case for Uganda. Pan Afr Med J 20:404.

Bell BP, Damon IK, Jernigan DB, Kenyon TA, Nichol ST, O'Connor JP, Tappero JW (2016) Overview, control strategies, and lessons learned in the CDC response to the 2014-2016 Ebola epidemic. Morb Mortal Wkly Rep 65(3):4-11.

Breman JG, Heymann DL, Lloyd G, McCormick JB, Miatudila M, Murphy FA, Muyembé-Tamfun JJ, Piot P, Ruppol JF, Sureau P, van der Groen G, Johnson KM (2016) Discovery and description of Ebola Zaire virus in 1976 and relevance to the West African epidemic during 2013-2016. J Infect Dis 214(suppl 3):S93-S101.

Callimachi, N. 2014. Fear of Ebola drives mob to kill officials in Guinea', The New York Times Sept 18, 2014

Dahl BA, Kinzer MH, Raghunathan PL, Christie A, De Cock KM, Mahoney F, Bennett S, Hersey S, Morgan OW (2016a) CDC's response to the 2014-2016 Ebola epidemic-Guinea, Liberia, and Sierra Leone. Morb Mortal Wkly Rep 65(3): $12-20$

Dahl BA, Kinzer MH, Raghunathan PL et al (2016b) CDC's response to the 20142016 Ebola epidemic_-Guinea, Liberia, and Sierra Leone. MMWR Suppl 65(Suppl-3):12-20 DOl: http://dx.doi.org/10.15585/mmwr.su6503a.

Dubois, M., \& Wake, C. (2015). The Ebola response in West Africa: exposing the politics and culture of international aid.

Ebola ça Suffit Ring Vaccination Trial Consortium (2015) The ring vaccination trial: a novel cluster randomised controlled trial design to evaluate vaccine 
efficacy and effectiveness during outbreaks, with special reference to Ebola. BMJ 351:h3740.

Gillespie AM, Obregon R, El Asawi R, Richey C, Manoncourt E, Joshi K, Naqvi S, Pouye A, Safi N, Chitnis K, Quereshi S (2016) Social mobilization and community engagement central to the Ebola response in West Africa: lessons for future public health emergencies. Glob Health Sci Pract 4(4):626-646. https://doi.org/10.9745/GHSP-D-16-00226.

Grinnell M, Dixon MG, Patton M, Fitter D, Bilivogui P, Johnson C, Dotson E, Diallo B, Rodier G, Raghunathan P (2015) Ebola virus disease in health care workers-Guinea, 2014. MMWR Morb Mortal Wkly Rep 64(38):1083-1087.

Gsell PS, Camacho A, Kucharski AJ, Watson CH, Bagayoko A, Nadlaou SD, Dean NE, Diallo A, Diallo A, Honora DA, Doumbia M, Enwere G, Higgs ES, Mauget T, Mory D, Riveros X, Oumar FT, Fallah M, Toure A, Vicari AS, Longini IM, Edmunds WJ, Henao-Restrepo AM, Kieny MP, Kéita S (2017) Ring vaccination with rVSV-ZEBOV under expanded access in response to an outbreak of Ebola virus disease in Guinea, 2016: an operational and vaccine safety report. Lancet Infect Dis 17(12):1276-1284

Henao-Restrepo AM, Longini IM, Egger M et al (2015) Efficacy and effectiveness of an rVSV-vectored vaccine expressing Ebola surface glycoprotein: interim results from the Guinea ring vaccination cluster-randomised trial. Lancet 386:857-866.

Heymann DL, Barakamfitiye D, Szczeniowski M, Muyembe-Tamfum JJ, Bele O, Rodier G (1999) Ebola hemorrhagic fever: lessons from Kikwit, Democratic Republic of the Congo. J Infect Dis 179(Suppl 1):S283-S286.

Kerstiëns B, Matthys F (1999) Interventions to control virus transmission during an outbreak of Ebola hemorrhagic fever: experience from Kikwit, Democratic Republic of the Congo, 1995. J Infect Dis 179(Suppl 1):S263-S267.

Key Events in the WHO Response to Ebola. 2015. Available at: http://www.who.int/ csr/disease/ebola/one-year-report/who-response/en/. Accessed on 1 Feb 2017.

Médicins sans Frontières, Stockholm Evaluation Unit (2016) Operation Centre Brussels (OCB) Ebola review: summary report. Medecins sans Frontieres, Stockholm.

Nyenswah T, Massaquoi M, Gbanya MZ et al (2015) Initiation of a ring approach to infection prevention and control at non-Ebola health care facilities-Liberia, January-February 2015. MMWR Morb Mortal Wkly Rep 64:505-508.

Olu O, Kargbo B, Kamara S, Wurie AH, Amone J, Ganda L, Ntsama B, Poy A, KutiGeorge F, Engedashet E, Worku N, Cormican M, Okot C, Yoti Z, Kamara KB, Chitala K, Chimbaru A, Kasolo F (2015) Epidemiology of Ebola virus disease transmission among health care workers in Sierra Leone, May to December 2014: a retrospective descriptive study. BMC Infect Dis 15:416.

Peters CJ, LeDuc JW (1999) An introduction to Ebola: the virus and the disease. J Infect Dis 179(Suppl 1):ix-xvi Review.

Protection and Security, Ebola in West Africa, ACAPS Briefing Note. 2014. Available at: http://www.globalhealth.org/wp-content/uploads/ACAPS_ Briefing_Note_Ebola_West_Africa_Impact_Protection_14_October.pdf. Accessed 1 Dec 2018.

Reference Module for Country Coordination at Country Level, Interagency Standing Committee 2015. https://interagencystandingcommittee.org/ system/files/cluster_coordination_reference_module_2015_final.pdf. Accessed on 12 May 2018.

Rosello A, Mossoko M, Flasche S, Van Hoek AJ, Mbala P, Camacho A, Funk S, Kucharski A, llunga BK, Edmunds WJ, Piot P, Baguelin M, Tamfum JJ (2015) Ebola virus disease in the Democratic Republic of the Congo, 1976-2014. elife 4:e09015.

Socio-Economic Impact of Ebola Virus Disease in West African Countries (2015) A call for national and regional containment, recovery and prevention. United National Development Group. Available at: http://reliefweb.int/sites/reliefweb int/files/resources/ebola-west-africa.pdf. Accessed 1 Dec 2016.

USAID West Africa Ebola outbreak fact sheet. 2016. https://www.usaid.gov/sites/ default/files/documents/1866/west_africa_ebola_fs12_09-30-2016.pdf.

WHO Ebola Virus Disease Situation Report. 2016. Available at: http://apps.who.int/ iris/bitstream/10665/208883/1/ebolasitrep_10Jun2016_eng.pdf?ua=1. Accessed 8 Mar 2017.

World Bank Group (2015) The Economic impact of Ebola on Sub-Saharan Africa: updated estimates for 2015. @ World Bank, Washington, DC. https:// openknowledge.worldbank.org/handle/10986/21303. License: CC BY 3.0 IGO.

World Health Organization. Factors that contributed to undetected spread of the Ebola virus and impeded rapid containment. 2015. Available at: http://www. who.int/csr/disease/ebola/one-year-report/factors/en/. Accessed 17 Dec 2016.

World Health Organization, Ebola virus disease external situation report. 2018. http://apps.who.int/iris/bitstream/handle/10665/272662/SITREP-EVD-DRC20180525-eng.pdf.

\section{Submit your manuscript to a SpringerOpen ${ }^{\circ}$ journal and benefit from:}

- Convenient online submission

- Rigorous peer review

- Open access: articles freely available online

- High visibility within the field

- Retaining the copyright to your article

Submit your next manuscript at $\gg$ springeropen.com 